\title{
Financial Impacts of Late-Gestation Heat Stress on Cow and Offspring Lifetime Performance ${ }^{1}$
}

\author{
L. T. Casarotto, J. Laporta, and G. E. Dahl²
}

Heat stress negatively affects the productivity and health of dairy cattle, and heat stress abatement is common for the lactating herd. However, recent studies indicate that heat stress of dry cows (i.e., late-gestation, non-lactating period between two subsequent lactations) dramatically affects the next lactation and the next generation. This publication describes the financial implications of ignoring heat stress in dry cows to assist dairy producers in decisions about installation of heat abatement measures and cooling cows in that stage of the production cycle.

In the United States, heat stress costs the dairy industry more than $\$ 1.5$ billion annually due to losses in production and reproductive performance and also an increase in morbidity and mortality of lactating dairy cows. That is why heat abatement practices such as shade, fans, soakers, and misters are commonly used by US dairies, especially for lactating cows. During the past decade, numerous studies have shown that the negative effects of heat stress observed during lactation also extend to the dry period. Exposure of dry cows to heat stress negatively affects milk production by reducing milk yield an average of $10 \mathrm{lb} / \mathrm{d}$. Initial estimates of the effect of heat stress exposure during the dry period suggest $\$ 810$ million in milk losses annually; therefore, cooling dry cows is profitable for $89 \%$ of the animals in the US dairies (Ferreira et al. 2016). However, this scenario does not account for the economic impact of the late-gestation heat stress on the performance of the offspring. The effects of in utero exposure to heat stress on survival, milk production, and reproduction across multiple generations have now been quantified, and those impacts persist for at least three subsequent lactations.

Environmental and maternal circumstances during pregnancy can affect offspring performance at adulthood. Fetal development and growth are maximal during the last trimester of gestation, which in dairy cows coincides with the dry period. Recent research (Monteiro et al. 2016; Skibiel et al. 2018) has shown that heifers born from heatstressed cows during late gestation are smaller and produce $11 \mathrm{lb} / \mathrm{d}$ less milk in the first lactation relative to heifers born from cooled cows. This evidence is suggestive of a longterm effect of the fetal environment on performance during adulthood.

When comparing a 10-year dataset with heifers born from cooled dams with heifers born from heat-stressed dams (Laporta et al. 2020), it was observed that heat-stressed daughters produced less milk during the first, second, and third lactations (Figure 1). In the first lactation, milk production of heat-stressed daughters was reduced by $4.9 \mathrm{lb} / \mathrm{d}$ during the 35 weeks in milk compared with the cooled daughters. During the second lactation, heatstressed daughters produced $5.1 \mathrm{lb} / \mathrm{d}$ less milk than cooled daughters. Both groups achieved peak lactation at 6 weeks in milk; however, the heat-stressed daughters produced $8.6 \mathrm{lb} / \mathrm{d}$ less than the cooled. In the third lactation, the differences between the groups were even greater, with the

1. This document is AN374, one of a series of the Department of Animal Sciences, UF/IFAS Extension. Original publication date November 2021. Visit the EDIS website at https://edis.ifas.ufl.edu for the currently supported version of this publication.

2. L. T. Casarotto, master's student, lactation physiology, Department of Animal Sciences; J. Laporta, assistant professor, mammary physiology, Department of Animal Sciences; and G. E. Dahl, professor, Department of Animal Sciences; UF/IFAS Extension, Gainesville, FL 32611.

The Institute of Food and Agricultural Sciences (IFAS) is an Equal Opportunity Institution authorized to provide research, educational information and other services

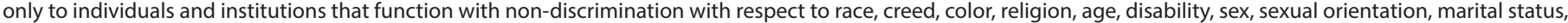

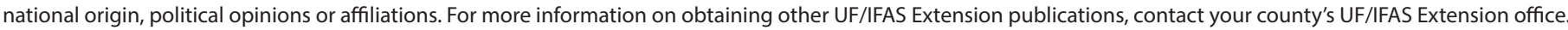
U.S. Department of Agriculture, UF/IFAS Extension Service, University of Florida, IFAS, Florida A \& M University Cooperative Extension Program, and Boards of County Commissioners Cooperating. Nick T. Place, dean for UF/IFAS Extension. 
heat-stressed daughters' production reduced by $14 \mathrm{lb} / \mathrm{d}$ compared to the cooled daughters. Milk components were also compared, but there were no differences in fat, lactose, or protein percentages between the heat-stressed and cooled animals.

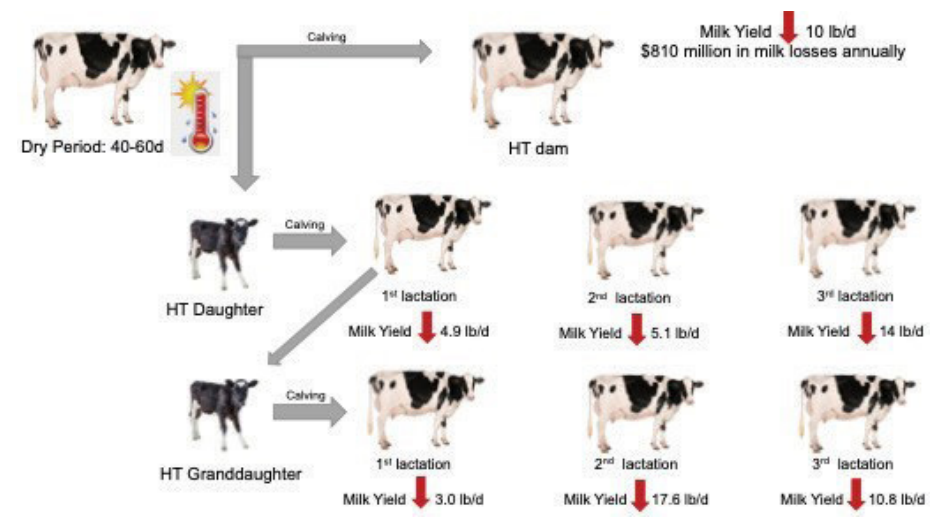

Figure 1. Diagram of heat stress effect during late gestation. Daughters and granddaughters born from heat-stressed dams produced less milk up to 35 weeks postpartum in all three lactations. Credits: Adapted from Laporta et al. (2020)

Milk production of the granddaughters was then compared. In the first lactation, heat-stressed granddaughters produced $3 \mathrm{lb} / \mathrm{d}$ less milk than cooled granddaughters. In addition, during the second and third lactations, heatstressed granddaughters had decreases of $17.6 \mathrm{lb} / \mathrm{d}$ and 10.8 $\mathrm{lb} / \mathrm{d}$ in milk yield, respectively, relative to cooled. Cooled granddaughters' energy-corrected milk (ECM) yield was higher in first, second, and third lactation. This indicates that the initial heat stress not only affects the daughter, but also the granddaughter of the first heat-stressed cow.

\section{Estimating Total Economic Losses Associated with Heat Stress in Dry Cows}

According to the USDA-ERS (2019), there were 9.4 million dairy cows present in the United States in 2018. Florida is the state with the greatest number of heat stress days per year (219 d), followed by Texas (164 d), California (69 d), and New Mexico (48 d). Milk production in 16 of the top 25 milk-producing states is significantly affected by heat stress in the dry period. Economically, California being the highest production state, is also the one most impacted by heat stress, followed by Texas, Wisconsin, Pennsylvania, New York, and Florida.

Given that heat-stressed daughters have a lower survival rate until first calving ( $71 \%$ vs. $83 \%$ ) relative to cooled daughters, the cost of rearing a heifer from birth to first calving may be $\$ 157.50$ greater if a heifer is born from a cow that has been exposed to heat stress during the dry period. Therefore, when accounting for the percentage of heat stress days per year per state, an average US dairy farm may have an extra heifer rearing cost of $\$ 14.30 / \mathrm{cow}$ per year. Extra rearing costs per cow per year have been calculated to be $\$ 47.30$ in Florida, representing losses of $\$ 5.7$ million per year. Collectively, the total losses associated with extra rearing costs of heifers in the United States amount to $\$ 134$ million per year (Figure 2). In addition, a reduced number of days between first calving and death or culling has a negative impact on profitability. An average US dairy farm may have an extra loss associated with a shorter productive life due to heat stress of $\$ 9.61$ per cow per year, which collectively in the US may represent losses of up to $\$ 90$ million if dry cows are not cooled (Figure 2).

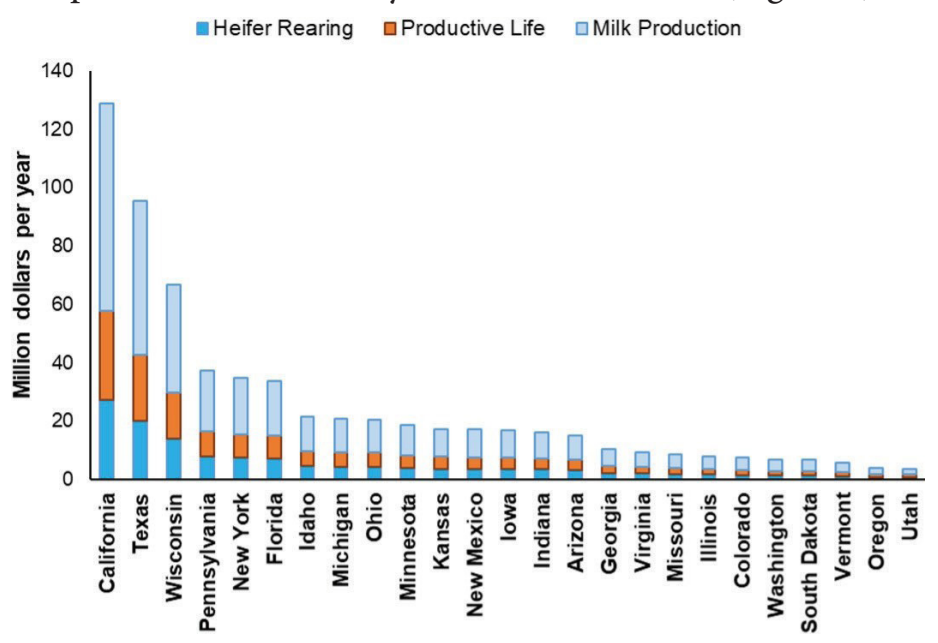

Figure 2. Annual economic loss (millions of dollars) associated with extra heifer rearing costs, reduced productive life, and milk yield of daughters born to dams exposed to heat stress during late gestation for the top 25 states with the most dairy cows, including Florida, the state with the most heat stress days per year.

Credits: Adapted from Laporta et al. (2020)

The milk losses associated with the reduced milk yield of daughters born to dams exposed to heat stress during late gestation translate into substantial economic losses nationally. For the top three states with the most dairy cows (California, Wisconsin, and New York) and the two states with the greatest number of heat stress days per year (Florida and Texas), the average annual milk loss of the daughter lactations was $276 \mathrm{lb}, 194 \mathrm{lb}, 207 \mathrm{lb}, 877 \mathrm{lb}$, and $659 \mathrm{lb}$, respectively. Collectively in the US, weighted by the number of cows in each state, annual losses of the daughters may be up to $\$ 371$ million ( $\$ 39 /$ daughter/year) if the milk price is $\$ 0.20 / \mathrm{lb}$ of milk and the income over feed cost (IOFC) is $\$ 0.15 / \mathrm{lb}$ of milk. In California, Wisconsin, New York, Florida, and Texas, the total economic losses of the daughters from heat-stressed dams may be approximately \$71 million, \$37 million, \$16 million, \$19 million, and \$53 million per year, respectively, and the average annual losses per cow per year for those states may be $\$ 41, \$ 29, \$ 31$, 
$\$ 155$, and $\$ 98$, respectively. When the milk price is reduced from $\$ 0.20$ per $\mathrm{lb}$ to $\$ 0.15$ per $\mathrm{lb}$, total weighted annual losses in the United States reach \$246 million, and the average loss per cow per year may be $\$ 26$.

\section{Conclusions}

Maternal heat stress during late gestation reduces daughter survivability and milk production for up to three lactations. The average US dairy cow may have a five-month reduction in productive life and lose an average of $265 \mathrm{lb}$ of milk per year if exposed to heat stress while developing in utero. Annual losses for the dairy sector arising from in utero heat stress, including milk loss in multiple lactations, reduced productive life, and additional heifer rearing costs, may be up to $\$ 595$ million if dry pregnant cows are not cooled. Additionally, dry-period heat stress seems to exert carryover effects on the survivability and the productivity of the second-generation offspring. Cooling dry pregnant cows is not only crucial to prevent subsequent lactation milk lossof the dam, but also to ensure optimal survivability and productivity of their daughters and granddaughters.

\section{References}

Collier, R. J., G. E. Dahl, and M. J. VanBaale. 2006. "Major Advances Associated with Environmental Effects on Dairy Cattle." J. Dairy Sci. 89:1244-1253. https://doi.org/10.3168/ jds.S0022-0302(06)72193-2

Fabris, T. F., J. Laporta, A. L. Skibiel, F. N. Corra, B. DadoSenn, S. E. Wohlgemuth, and G. E. Dahl. 2019. "Effect of Heat Stress during Early, Late, and Entire Dry Period on Dairy Cattle." J. Dairy Sci. 102:5647-5656. https://doi. org/10.3168/jds.2018-15721

Ferreira, F. C., R. S. Gennari, G. E. Dahl, and A. De Vries. 2016. "Economic Feasibility of Cooling Dry Cows across the United States." J. Dairy Sci. 99:9931-9941. https://doi. org/10.3168/jds.2016-11566

Laporta, J., F. C. Ferreira, V. Ouellet, B. Dado-Senn, A. K. Almeida, A. De Vries, and G. E. Dahl. 2020. "LateGestation Heat Stress Impairs Daughter and Granddaughter Lifetime Performance." J. Dairy Sci. 103:7555-7568. https:// doi.org/10.3168/jds.2020-18154

Monteiro, A. P. A., S. Tao, I. M. T. Thompson, and G. E. Dahl. 2016. "In Utero Heat Stress Decreases Calf Survival and Performance through the First Lactation." J. Dairy Sci. 99:8443-8450. https://doi.org/10.3168/jds.2016-11072
Skibiel, A. L., B. Dado-Senn, T. F. Fabris, G. E. Dahl, and J. Laporta. 2018. "In Utero Exposure to Thermal Stress Has Long Term Effects on Mammary Gland Microstructure and Function in Dairy Cattle." PLoS One 13:e0206046. https:// doi.org/10.1371/journal.pone.0206046

St-Pierre, N. R., B. Cobanov, and G. Schnitkey. 2003. "Economic Losses from Heat Stress by U.S. Livestock Industries.” J. Dairy Sci. 86 (E. Suppl.): E52-E77.

Tao, S., and G. E. Dahl. 2013. "Invited Review: Heat Stress Effect during Late Gestation on Dry Cows and Their Calves." J. Dairy Sci. 96:4079-4093. https://doi.org/10.3168/ jds.2012-6278

USDA-ERS. 2019. "Milk Cows and Production by State and Region.” Accessed July 20, 2019. https://www.ers.usda.gov/ data-products/dairy-data/ 